\title{
John Thomas Crowell, Jr. (1898-1985)
}

Jack Crowell supported, led, and advised the work of innumerable people for many years in Greenland, northern Canada, the Arctic Ocean and Antarctica. He was a master mariner by training and he applied the discipline and skills of that calling throughout the transition of polar development from the age of sail to the jet age. He was involved in the urgencies of war, the construction of research facilities, the training of students, and the safe conduct and support of scientists. He always took a personal interest in what students, scientists, mariners, military people, common folk, and colleagues of other nations were trying to do; every aspect of polar activity and development interested him, and he gave it his best support for more than forty years.

John Thomas Crowell, Jr., was born in the fishing port of Gloucester, Massachusetts. He graduated at age 18 from the Massachusetts Nautical School, having served two years on the square-rigged, coal-burning school ship Ranger. During World War I his ship was torpedoed in the Bay of Biscay and he was hospitalized for two months. Following the war he served for several voyages on the British full-rigged sailing ship Brynhilda trading between New York, Liverpool, and Halifax; he was second mate on the four-masted schooner Blanche Pendleton; and he was chief officer on several steamers serving the west coast of South America. In 1924 Crowell earned an Unlimited Master Mariner's license for sail and steam anywhere in the world.

In 1926 he began a nearly continuous career in the Arctic and Antarctic spanning over forty years. In 1926 and 1927 Crowell was master of the schooners Sachem and Radio, voyaging to Greenland, Baffin Island, and Labrador. In 1927 he was also in command of Donald MacMillan's schooner Bowdoin, cruising extensively throughout Frobisher Bay, Baffin Island. Crowell made several voyages as master and mate of the Bowdoin in the early 1930s, sailing to Iceland, East Greenland, and Labrador. In 1937 he was master of the famed Gloucester fishing schooner Gertrude L. Thebaud in a voyage to Frobisher Bay.

In 1940 Crowell was commissioned major in the U.S. Army Air Corps and appointed officer-in-charge of Crystal Two, the project that led to the establishment of Frobisher air base. Crowell's party spent the winter on an island in Frobisher Bay, a site initially thought to be a possible location for an airstrip. The following summer Crowell was one of the group that selected the permanent site for Frobisher air base near the Sylvia Grinnell River.

In the summer of 1941 Crowell served as pilot for the numerous vessels in passage in and out of Frobisher Bay, bringing construction personnel, materials, and equipment for the airfield. The combination of great tides, strong currents, pinnacle rocks, and incomplete charts of the area demanded exceptional care to insure safe transit of the vessels.

Jack Crowell served in Greenland in 1942, and in the winter of 1943 he organized and trained the Arctic Service Unit for the Army Air Corps to support aircraft and to rescue downed air crews flying the arctic route to Europe. He was officerin-charge of a weather and military station at Comanche Bay on the east coast of Greenland in 1943-44. At war's end he

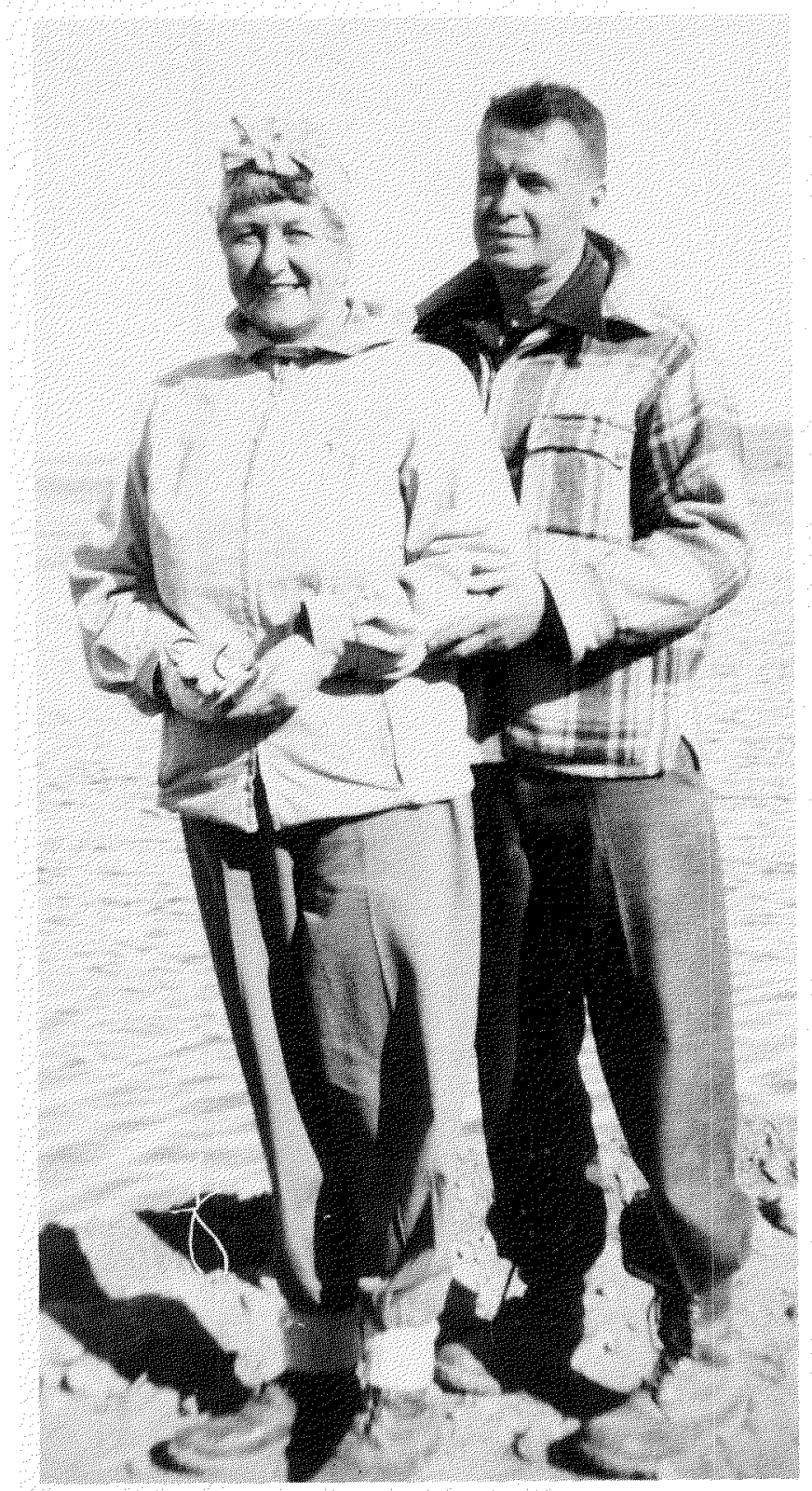

Alice and Jack Crowell at Thule, Greenland, in 1952.

was a lieutenant colonel and had received the Legion of Merit for his arctic work.

After the war he returned to his island home near Isle au Haut, Maine, to pursue commercial fishing. In 1951 he was appointed officer-in-charge for two years at the U.S. Weather Bureau station in Thule, Greenland, just before and during the construction of the U.S. Air Force base. When the Weather Bureau withdrew from Thule, Crowell joined the staff of the Northeast Air Command at Fort Pepperell in St. John's, Newfoundland, as a technical advisor in the Arctic Division. He was thus directly involved in planning and the initial site landings for DEW Line stations in Canada and HIRAN sites on the Greenland Ice Cap. He was advisor to 
the reactivation of T-3, Fletcher's Ice Island, in the Arctic Ocean for the International Geophysical Year, and he was subsequently advisor to the U.S. Air Force for the examination of unprepared emergency airstrips at Polaris Promontory, Hall Land, and Bronlund's Fiord, Peary Land, North Greenland.

Crowell then joined the National Science Foundation as special projects officer. He was responsible for the conversion and commissioning of the Eltanin for Antarctic oceanographic research, for the planning and construction of the research vessel Hero, and for planning an Arctic Ocean drifting research barge - a concept that has not yet come to pass. Crowell made two trips for NSF on icebreakers to the Antarctic Peninsula to select a site for Palmer Station.

Crowell retired to Kimball Island on the coast of Maine, where he and his wife, Alice, fished for lobsters for a number of years.

An island in Frobisher Bay, Baffin Island, a harbor in Labrador, and a mountain in Antarctica are named for Crowell, facts that he never mentioned.

Jack Crowell never appeared in headlines because he was a quiet, modest man, who avoided publicity or notoriety. He was extremely conscientious in carrying out his responsibilities and, most likely a benefit of his early training in com- mercial sail, he had no patience with pretense or carelessness. He was credited with saving the lives of three RAF airmen, downed and in extremis on the east coast of Greenland in October 1943, simply because he paid close attention to his surroundings while on patrol on the MV Polarbjorn.

He had a great liking for native people, in whom he took a particular interest. Dr. Alexander Forbes wrote: "With us was Paluchi, an Eskimo patriarch of Frobisher Bay whom Crowell had taken on as a guide, philosopher and friend, factotum and counsel soon after his [Crowell's] arrival the previous October.'

Jack Crowell made friends easily throughout the North, and he loved to yarn, with a characteristically gentle sense of humor, about ships and the sea, fishing, the polar regions, and what other people were doing there.

\section{REFERENCE}

FORBES, ALEXANDER. 1953. Quest for a Northern Air Route. Cambridge: Harvard University Press.

Spencer Apollonio

31 Eastern Avenue Boothbay Harbor, Maine 04538 U.S.A. 